Key-words: Morbidity. Mortality. Schistosomiasis. Onchocerciasis. Intestinal Helminths. Visceral Leishmaniasis: Malaria. Asca-

riases. Hookworm infections.

\title{
MORBIDITÉ ET MORTALITÉ DUES AUX MALADIES PARASITAIRES EN L'AN 2000
}

\author{
H. M. GILLES
}

RÉSUMÉ

"L'imprudent se précipite où le sage hésiterait d'avancer ». "Fools rush in where Angels fear to tread " est un proverbe anglais que je connais trop bien; et pourtant, j'ai accepté de faire cet exposé sur un sujet qui abonde en spéculations et en incertitudes. Je m'en tiendrai à cinq des maladies principales à savoir, la schistosomiase, l'onchocercose, les helminthes intestinaux avec en particulier l'ascaridiose et l'ankylostomiase, la leishmaniose viscérale et le paludisme : elles représentent des maladies dont j'ai une expérience personnelle.

Dans mes prédictions je me baserai sur trois hypothèses fondamentales importantes:

1 - Les gouvernements du Tiers-Monde devront montrer une " volonté politique » bien plus grande que celle que l'on peut voir de nos jours afin de réduire la mortalité et la morbidité provenant de ces maladies.

2 - Les gouvernements du " monde industriel » devront accepter de pourvoir, en cas de besoin et sur demande, à une aide économique pour ces aspects déterminés de la santé.

3 - Tous les gouvernements devront montrer un engagement sincère à «La Santé pour tous ".

Bien que le contrôle et dans certains cas, l'élimination de certaines maladies parasitaires, devront attendre que des progrès au niveau socio-économique, éducatif, et dans l'environnement aient été effectués dans les pays du Tiers-Monde, nous avons déjà à notre disposition des moyens de réduire la morbidité et la mortalité dans certaines régions.

\section{La Schistosomiase}

Nous avons des preuves au Brésil, en Egypte et dans d'autres pays que les agents chimiothérapeutiques disponibles peuvent réduire morbidité et mortalité quand ils sont distribués sélectivement dans la communauté. D'ici l'an 2000 , la découverte d'un vaccin aura été accomplie. L'action conjuguée de la chimiothérapie et du vaccin devrait rendre possible l'éradication.

\section{L'Onchocercose}

L'utilisation de l'ivermectine devrait éliminer la cécité, conséquence pathologique la plus sérieuse de la maladie, d'ici l'an 2000. Les moyens logistiques de distribution de ce produit pharmaceutique ont été examinés dans le détail et ses conséquences étudiées. De plus, ce produit est offert gratuitement aux pays du TiersMonde affectés par ce problème.

\section{Helminthiases intestinales}

Des produits antihelminthiques variés de bonne qualité et admi- nistrés périodiquement permettent de réduire le portage intestinal des vers intestinaux à un niveau cliniquement acceptable. Le prix de ces produits baisse régulièrement. Je ne prévois aucune découverte de vaccin efficace pour combattre l'ascaridiose ou l'ankylostomiase d'ici l'an 2000.

Contrairement aux maladies dues aux protozoaires, la chimiorésistance des maladies helminthiques dont nous avons parlées, semble peu probable tant en étendue qu'en intensité.

\section{Leishmaniose viscérale}

L'épidémiologie complexe de cette maladie, l'absence de médicament véritablement efficace et le manque d'initiative dans la poursuite des recherches, n'annoncent rien de bon pour l'avenir. A moins d'une découverte inattendue en immunologie ou en biologie moléculaire qui aboutirait à la création d'un vaccin, je ne prévois aucun changement dans la morbidité et la mortalité de cette maladie d'ici l'an 2000.

\section{Le Paludisme}

En ce moment, le paludisme est au croisement de routes. Un grand effort global est nécessaire pour contrecarrer un état de fait où beaucoup de choses laissent à désirer. Contrairement à la Leishmaniose qui est souvent connue comme la "Cendrillon» des maladies dues à des protozoaires, le paludisme est une maladie excessivement émotive et politiquement explosive ayant une morbidité définie et une mortalité appréciable. La prise de conscience de la gravité de la situation présente semble avoir finalement frappé les intéressés. Les progrès, quoiqu'échelonnés, ont été continus et des savants éminents de réputation mondiale sont engagés activement dans des recherches. Je suis vraiment persuadé que des " percées " en chimiothérapie et dans le développement d'un vaccin auront lieu d'ici l'an 2000 et nous permettront de réduire morbidité et mortalité de cette affection.

\section{CONCLUSION}

Tout en faisant ces prédictions personnelles, je me console du fait que si je suis encore en vie en l'an 2000 , toute critique ou peut-être même toute raillerie sur mon compte sera voilée d'indulgence à cause du grand âge que j'aurai atteint.

Department of Pharmacology and Therapeutics of Liverpool, William P. Martley Building, Afhton street, POB 147, Liverpool L69 3BX, G.-B.. 
SummaRy: Morbidity and mortality from parasitic diseases in the year 2000 .

«Fools rush in where Angels fear to tread» is an English proverb of which I am only too well aware; yet I have accepted to speak on the above subject fraught as it is with speculations and uncertainties. I shall confine myself to only five of the major parasitic diseases namely, the schistosomiases, onchocerciasis, the intestinal helminths in particular ascariasis and hookworm infections, visceral leishmaniasis, and malaria - with all of which I have had same personal experience.

In my predictions I shall have to make three basic and important assumptions.

1 - Governments in the Third World will have shown a greater "political will" than has hitherto been the case to reduce the morbidity and mortality from these diseases.

2 - Governments in the "industrialised world" will be prepared to provide substantial (if necessary) economic aid towards these specific aspects of health, if requested.

3 - The commitment to " health for all" is a genuine one.

Whereas the control and in some instances the elimination of some of the parasitic diseases may have to await considerable improvements in the socio-economic, educational and environmental status of many of the countries in the Third World, tools are already at our disposal to reduce morbidity and mortality from some of them.

\section{The Schistosomiases}

Evidence is already available from Brazil, Egypt and elsewhere that the available chemotherapeutic agents are able to reduce morbidity and mortality when given selectively at the community level. Progress towards a vaccine should have been achieved by the year 2000. The combination of chemotherapy and a vaccine should make elimination a possibility.

\section{Onchocerciasis}

With the advent of Ivermectin there is no reason why blindness -the most serious pathological effect of this disease- should not be eliminated by the year 2000 . The logistics of drug delivery have been worked out, the acceptability of side effects assessed and furthermore the drug is available free of charge to Third World countries affected by the problem.

\section{Intestinal helminthiasis}

Excellent broad-spectrum anthelminthics given periodically will reduce heavy worm burdens to the level of no clinical significance. The cost of these compounds is progressively coming down. I do not see the prospect of a successful vaccine by the year 2000 neither for ascaris nor hookworm.

Unlike the protozoal diseases, multidrug resistance with the helminthic diseases mentioned seems less likely to occur both in extent and degree.

\section{Visceral leishmaniasis}

The variable epidemiology of this disease, the present lack of a really satisfactory drug, the seemingly lack of incentive to produce one, does not augur well for the future. Unless an unexpected break-through in the immunology and molecular biology field occurs resulting in a vaccine, I do not see much change in the morbidity and mortality of this disease occurring by the year 2000 .

\section{Malaria}

At present malaria is at the cross-roads - a really concerted effort will be required to reverse the present highly unsatisfactory trend. Unlike leishmaniasis which is often not injustifiably referred to as the "Cinderella " of the protozoal diseases, malaria is a highly emotive and politically charged disease with definable morbidity and appreciable mortality. An awareness of the seriousness of the present situation seems at last to have been realised by all concerned-progress although staggered has been continuous and some of the most eminent research scientists in the world are actively involved. I am personally hopeful that "breakthroughs " in both chemotherapeutic and vaccine development will occur by the year 2000 enabling us to reduce morbidity and mortality.

\section{CONCLUSION}

In making these personal predictions I am comforted by the fact that even if I am still around by the year 2000 , criticism or even ridicule may be mollified by virtue of my venerable age then. 